Aim of the study: Lactobacillus casei (L. casei) has been shown to inhibit the proliferation of several types of cancer in vivo, but its effect on cervical cells has not been reported. We incubated cells of the human cervical cell lines Caski and HeLa with extracts of $L$. casei and investigated its effects on the growth of the cells and possible synergy with anticancer drugs.

Material and methods: Cell-free extracts of $L$. casei were prepared and purified. Cultures of Caski and HeLa cells adhering to tissue culture plates were treated with $L$. casei extract. The effects of $L$. casei extract on the growth of cancer cells and its possible synergy with anti-cancer drugs in cervical cancer cell lines were investigated. The cells were treated with $L$. casei extract alone, anti-cancer drugs alone [doxorubicin, paclitaxel, 5-fluorouracil (5-FU), and cisplatin], or L. casei extract plus anti-cancer drugs.

Results: L. casei extract had no significant effect on the growth rate of the two cell lines. Anti-cancer drugs alone induced growth inhibition, but there was no synergistic effect of $L$. casei extract on growth inhibition.

Conclusions: L. casei extract does not have a potent effect on the viability of cervical cancer cells in vitro. In addition, L. casei extract has no synergistic effect on the inhibition of growth of cancer cells in the presence of anticancer drugs.

Key words: Lactobacillus casei, cell viability, apoptosis, chemotherapy.

Contemp Oncol (Pozn) 2015; 19 (4): 306-312 DOI: $10.5114 /$ wo.2014.45292

\section{The effect of Lactobacillus casei extract on cervical cancer cell lines}

\author{
Soo-Nyung Kim ${ }^{1}$, Won Moo Lee ${ }^{1^{*}}$, Kyoung Sik Park ${ }^{2}$, Jong Bin Kim³, \\ Dae Jong $\mathrm{Han}^{4}$, Jaeman $\mathrm{Bae}^{2^{*}}$
}

${ }^{1}$ Konkuk University Medical Center, Seoul, South Korea

${ }^{2}$ Hanyang University College of Medicine, Seoul, South Korea

${ }^{3}$ Seoul National University College of Medicine, Seoul, South Korea

${ }^{4}$ Biomedical Research Institute, Seoul National University Hospital, Seoul, South Korea

* These authors contributed equally to this work.

\section{Introduction}

Lactobacillus casei (L. casei) is a Gram-positive, non-pathogenic bacterium, found mainly in the human intestine [1]. It produces lactic acid as a fermentation product of carbohydrates [2] and is used as an acid-producing starter culture in the preparation of fermented foods [3]. As a nutritional supplement, $L$. casei has been shown to lead to improvements in intestinal microbial balance [4], arthritis [5], and type 1 diabetes [6]. It has also been shown to have anti-cancer effects via growth inhibition in leukaemia [7] and liver cancer [8]. Many female cancer patients take L. casei as a nutritional supplement.

Cervical cancer is the second leading cause of cancer mortality among women worldwide. In Korea, in the past, cervical cancer had the highest incidence, but in recent years thyroid cancer and breast cancer have overtaken it. According to Korean Central Cancer Registry Project Statistics, cervical cancer accounted for one-eighth of all carcinomas in Korean women in 2009 [9]. The frequency of cervical cancer is gradually falling, largely because regular cancer screening prevents dysplasia and carcinoma in situ from progressing to invasive cancer. However, cervical cancers occupy an important position among all cancers if carcinoma in situ and dysplasia are included. Cervical cancer is associated with viral infection [10]; the most important cause of cervical cancer is persistent cervical infection with human papillomavirus (HPV) [11]. Bacterial vaginosis (BV) is caused by an alteration in the vaginal flora involving a decrease in Lactobacilli and predominance of anaerobic bacteria. A meta-analysis has shown that BV is associated with uterine cervical HPV infection [12]. Development of vaccines for the prevention and treatment of cervical cancer is ongoing.

Traditional treatment methods for women's cancer are surgery, radiation and chemotherapy. Surgery is carried out in cases with no metastasis to other organs, whereas chemotherapy and radiation are performed after surgery or in cases where there is metastasis to other organs. Many female patients take nutritional supplements, such as anti-oxidant agents, fish oil, and L. casei, before, during, and after cancer therapy [13]. The effect of these nutritional supplements depends on the cancer type and the patient's lifestyle. However, there are few studies of the effects of anti-cancer drugs plus nutritional supplements in cancer. The aim of the current study was to examine the effect of $L$. casei extract on growth inhibition in cervical cancer cells.

\section{Material and methods}

\section{Bacteria strains and growth conditions}

Lactobacillus casei ATCC393 (American Type Culture Collection) was obtained from the Korean Culture Centre of Microorganisms (KCCM). The bacteria were grown in Lactobacillus Mann-Rogosa-Sharp (MRS) broth (Difco 
0881) at $37^{\circ} \mathrm{C}$. The growth medium consisted of $10 \mathrm{~g}$ Difco proteose peptone No. 2, $10 \mathrm{~g}$ beef extract, 5 g yeast extract, 20 g glucose, 1 g sorbitan monooleate complex (Tween 80), $5 \mathrm{~g}$ ammonium acetate, $5 \mathrm{~g}$ sodium acetate, $2 \mathrm{~g} \mathrm{~K}_{2} \mathrm{HPO}_{4}$, $1 \mathrm{~g} \mathrm{MgSO}_{4}-7 \mathrm{H}_{2} \mathrm{O}$, and $0.05 \mathrm{~g} \mathrm{MnSO}_{4}-4 \mathrm{H}_{2} \mathrm{O}$. The $\mathrm{pH}$ of the growth medium was adjusted to 6.5 after mixing the components.

Preparation and purification of cell-free extracts of Lactobacillus casei

Lactobacillus casei was grown in MRS medium for two days until the mid-exponential phase (A.600 $=0.5)$, then it was centrifuged and re-suspended in $500 \mu \mathrm{l} 1 \times$ phosphate-buffered saline (PBS) with two further washes, and disrupted on ice for 1 minute with a Sonic Dismembrator at 5 Watts. The extract was centrifuged and the supernatant

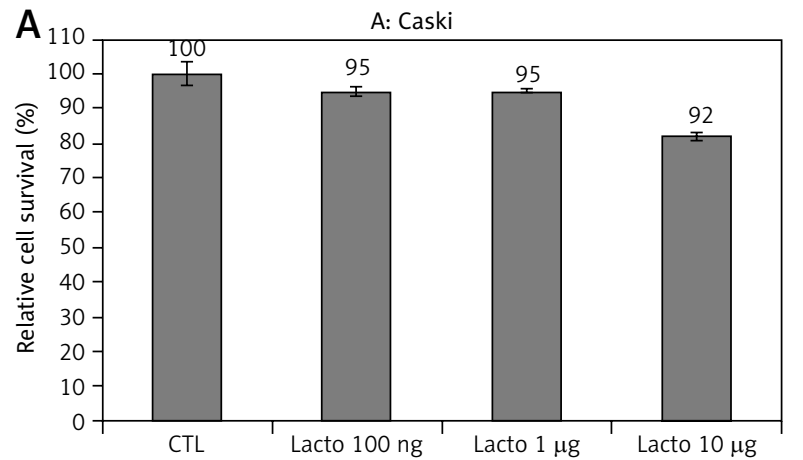

filtered through a $0.2 \mu \mathrm{m}$ syringe filter. The protein concentration of the extract was assayed by the Bradford method, with bovine serum albumin (BSA) as the standard.

\section{Cell culture}

CaSki and HeLa cell lines were obtained from the Korean Cell Line Bank (Seoul, South Korea). The cells were cultured on tissue culture dishes (Falcon; San Jose, CA, USA) in Dulbecco's modified Eagle's medium (DMEM) containing $10 \%$ foetal bovine serum (FBS). Aliquots of $5 \times 10^{5}$ cells/ dish were cultured at $37^{\circ} \mathrm{C}$ in a humidified atmosphere containing $5 \% \mathrm{CO}_{2}$.

\section{Cell growth rate measurement}

For each cell line, $5 \times 10^{5}$ cells were seeded in DMEM containing 10\% FBS. After 24 hours the cells were washed

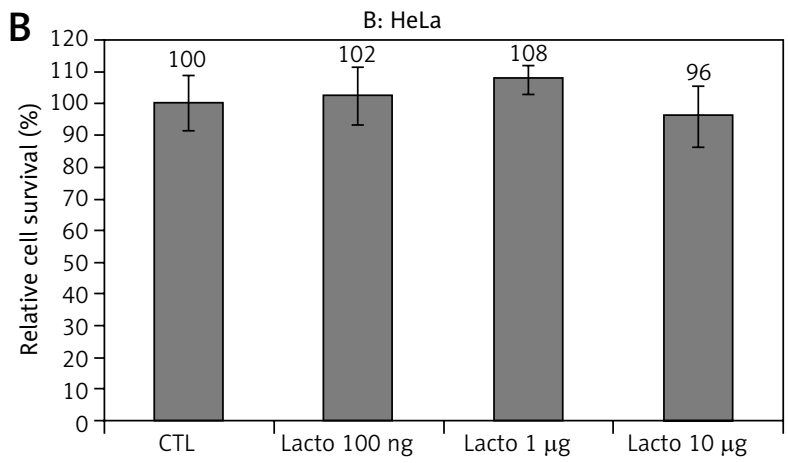

Fig. 1. Effect of $L$. casei extract on cervical cancer cell lines. A) Caski and B) HeLa cells were treated with extract of $L$. casei at 1, 10, or 100 M. Cells were stained with trypan blue to determine viability. Viable cell numbers in the treated cultures are shown relative to the numbers in the controls. The data are means of at least three independent experiments with the corresponding standard errors

A

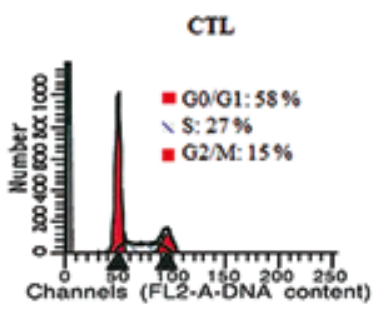

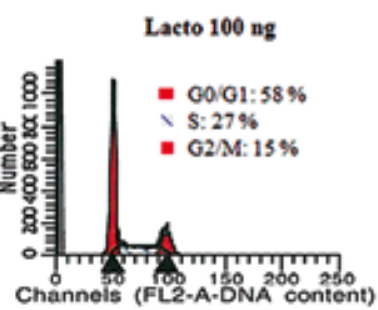

A: Caski
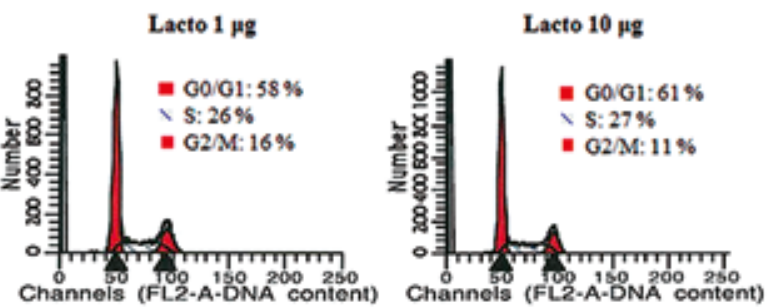

B

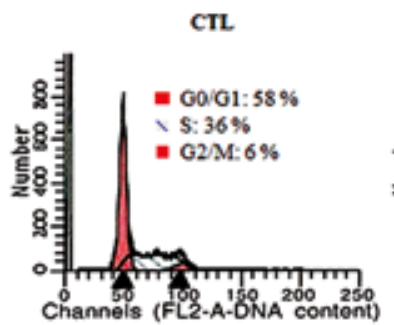

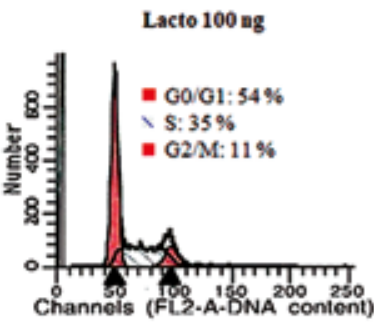

Lacto 1 Hg

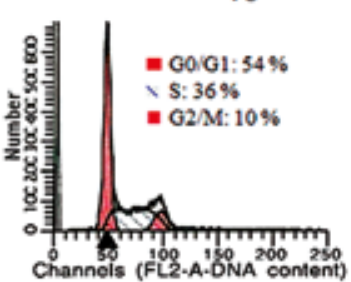

Lacto $10 \mathrm{\mu g}$

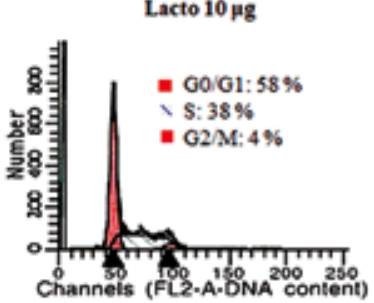

Fig. 2. Lactobacillus casei treatment does not affect cell cycle phases. A) Caski cells and B) HeLa cells were treated with the indicated amounts of the extract of $L$. casei for 72 hours. The percentages of cells at each stage of the cell cycle were analysed by flow cytometry after DNA staining with propidium iodide. The data are from a representative experiment 

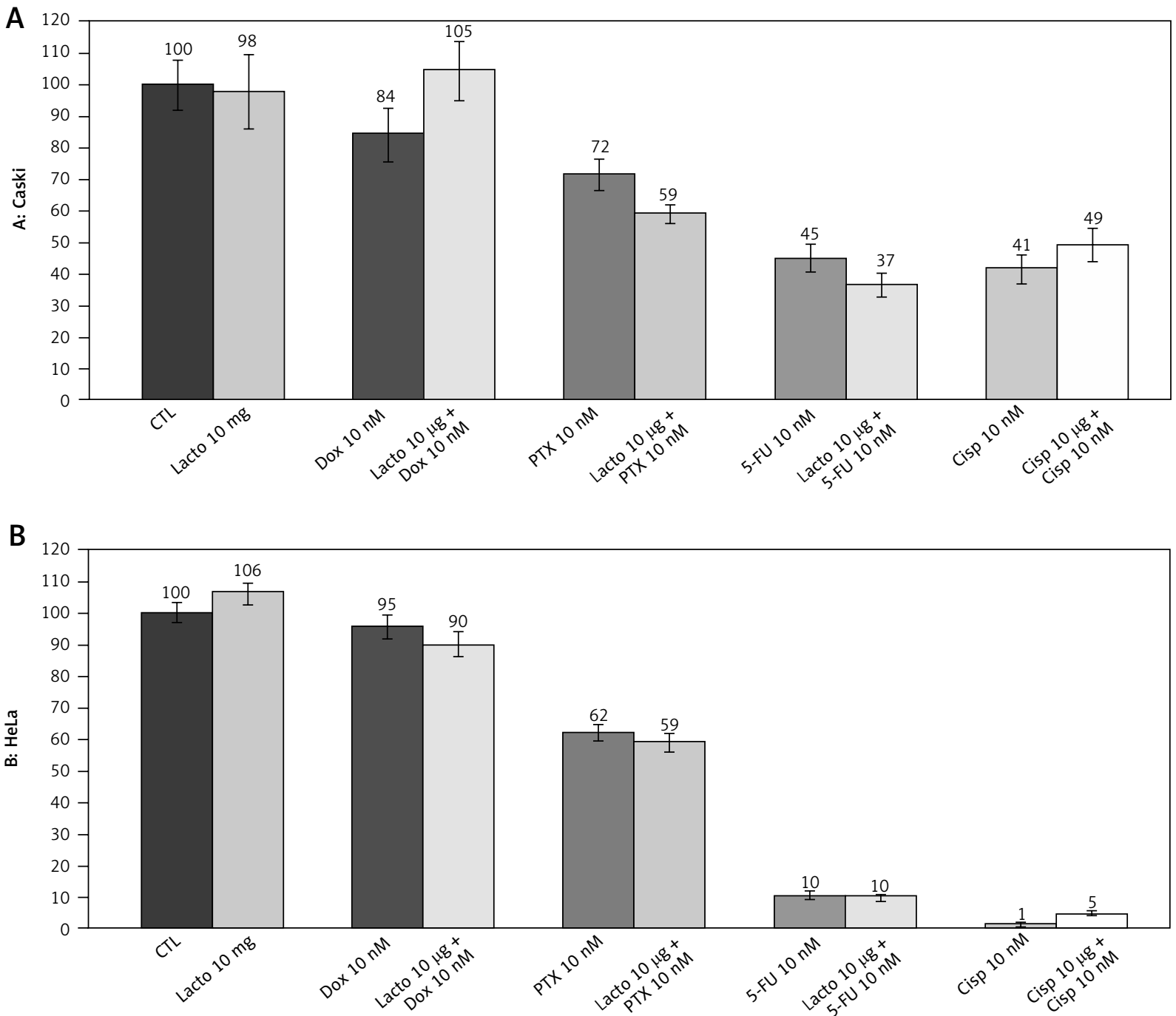

Fig. 3. Growth rate of CaSki and HeLa cells after treatment with Lactobacillus casei extract and anti-cancer drugs. A) Caski cells. B) HeLa cells. Aliquots of $5 \times 10^{5}$ cells were seeded in Dulbecco's modified Eagle's medium (DMEM) containing $10 \%$ foetal bovine serum (FBS). Cells were treated with distilled water, followed by L. casei extract $(10 \mu \mathrm{g} / \mathrm{ml})$, anti-cancer drugs (doxorubicin $10 \mathrm{nM}$, 5-fluorouracil (5-FU) $10 \mathrm{nM}$, paclitaxel $10 \mathrm{nM}$, cisplatin $10 \mathrm{nM}$ ) or L. casei extract $(10 \mu \mathrm{g} / \mathrm{ml}$ ) plus anti-cancer drugs (doxorubicin $10 \mathrm{nM}, 5$-FU $10 \mathrm{nM}$, paclitaxel $10 \mathrm{nM}$, cisplatin $10 \mathrm{nM}$ ) for 72 hours. Cells were then stained with trypan blue to determine viability. Viable cell numbers in the treated cultures are shown relative to controls

with PBS and cultured in fresh medium. Cells were treated with distilled water, followed by $100 \mathrm{ng}, 1 \mu \mathrm{g}$, or $10 \mu \mathrm{g} / \mathrm{ml}$ L. casei extract alone, anti-cancer drugs alone (doxorubicin $10 \mathrm{nM}, 5-\mathrm{FU} 10 \mathrm{nM}$, paclitaxel $10 \mathrm{nM}$, cisplatin $10 \mathrm{nM}$ ), or L. casei extract $(10 \mu \mathrm{g} / \mathrm{ml})$ plus anti-cancer drugs (doxorubicin $10 \mathrm{nM}, 5-\mathrm{FU} 10 \mathrm{nM}$, paclitaxel $10 \mathrm{nM}$, cisplatin $10 \mathrm{nM}$ ) for 72 hours. The growth rate was determined using an inverted microscope (Olympus Model IX51, Tokyo, Japan) equipped with a DP50 camera system (Olympus, Tokyo, Japan) using the $0.4 \%$ trypan blue dye exclusion method. Cell survival was measured as a percentage of the total number of cells (viable plus non-viable). Mean survival was determined by counting four randomly selected non-overlapping fields. Each culture dish represents one determination, with each experiment replicated independently 4-6 times using different cultures.

\section{Cell cycle analysis}

CaSki and HeLa cells were seeded at a density of $1 \times$ $10^{5}$ cells $/ \mathrm{ml}$ in DMEM medium containing $10 \%$ FBS. After 24 hours they were incubated with distilled water, L. casei extract $(10 \mu \mathrm{g} / \mathrm{ml})$, or $L$. casei extract $(10 \mu \mathrm{g} / \mathrm{ml})$ plus anti-cancer drugs (doxorubicin $10 \mathrm{nM}, 5-\mathrm{FU} 10 \mathrm{nM}$, paclitaxel $10 \mathrm{nM}$, cisplatin $10 \mathrm{nM}$ ) for 72 hours. The cells were then incubated with $100 \mu \mathrm{g} / \mathrm{ml}$ RNase A for 1 hour at $37^{\circ} \mathrm{C}$, and stained with $10 \mu \mathrm{g} / \mathrm{ml}$ propidium iodide (PI). Flow cytometry was performed in triplicate for each experiment using an FACS Calibur system (BD Biosciences, San Jose, (A, USA).

\section{Analysis of apoptosis by annexin $\mathrm{V}$ staining}

CaSki and HeLa cells were seeded at a density of $1 \times$ $10^{5}$ cells $/ \mathrm{ml}$ in DMEM medium containing 10\% FBS. After 
A

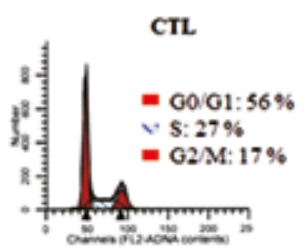

Lacto $10 \mu \mathrm{g}+$ PTX $10 \mathrm{nM}$

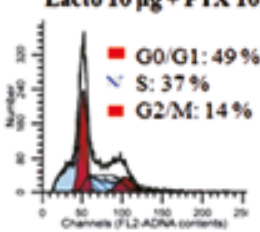

B
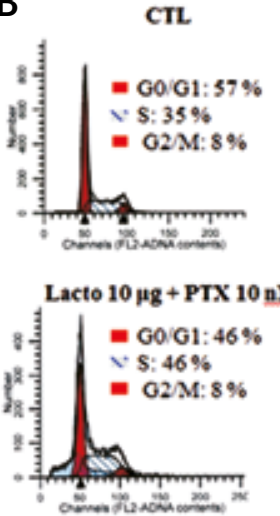

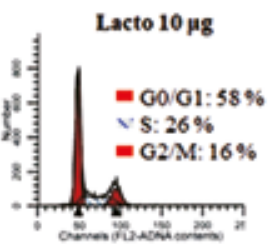

5-FU $10 \mathrm{nM}$
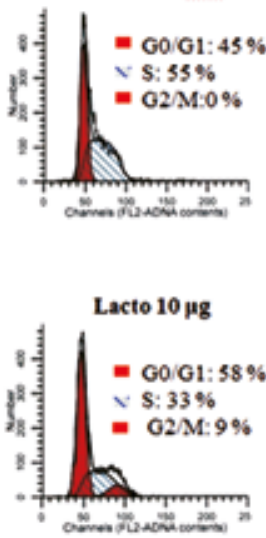

$5-F C 10 \mathrm{nM}$

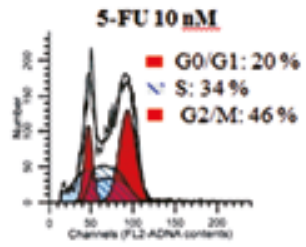

A: Caski
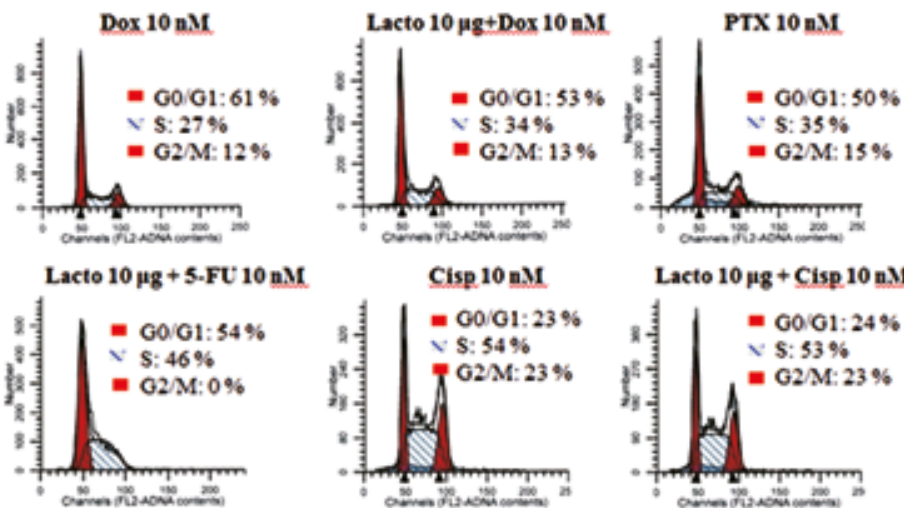

Cisp. 10 nM
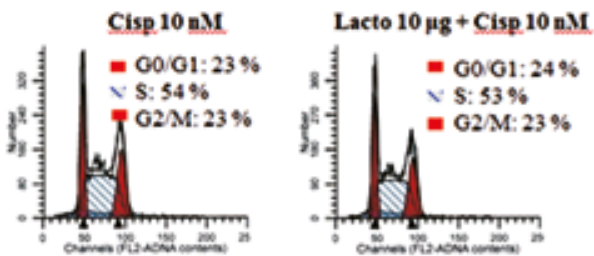

B: HeLa
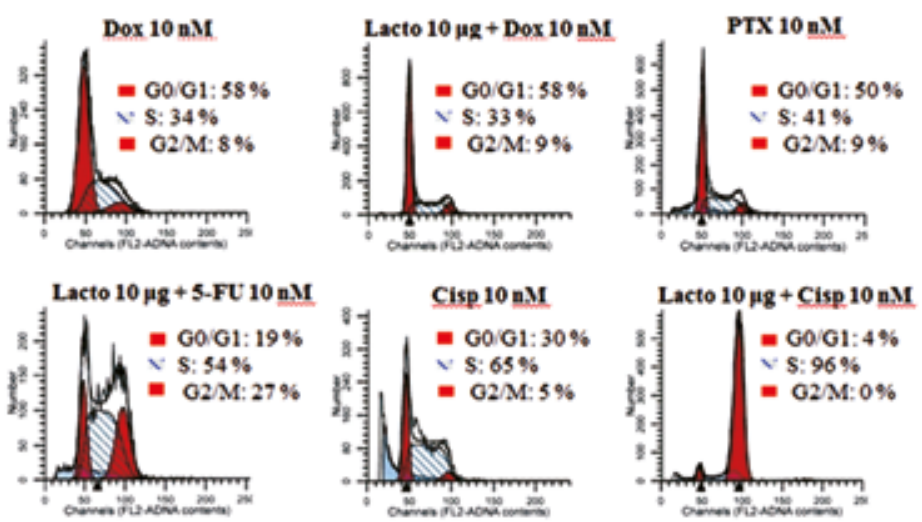

Fig. 4. Cell cycle analysis for CaSki and HeLa cells after treatment with L. casei extract and anti-cancer drugs. A) CaSki cells. B) HeLa cells. Aliquots of $5 \times 10^{5}$ cells were seeded in Dulbecco's modified Eagle's medium (DMEM) containing 10\% foetal bovine serum (FBS). Cells were treated with distilled water, followed by L. casei extract $(10 \mu \mathrm{g} / \mathrm{ml})$, anti-cancer drugs (doxorubicin $10 \mathrm{nM}, 5$-fluoruracil (5-FU) $10 \mathrm{nM}$, paclitaxel $10 \mathrm{nM}$, cisplatin $10 \mathrm{nM})$ or L. casei extract $(10 \mu \mathrm{g} / \mathrm{ml})$ plus anti-cancer drugs (doxorubicin $10 \mathrm{nM}, 5$-FU $10 \mathrm{nM}$, paclitaxel $10 \mathrm{nM}$, cisplatin $10 \mathrm{nM}$ ) for 72 hours. The percentages of cells in each stage of the cell cycle were analysed by flow cytometry

24 hours, they were incubated with distilled water, L. casei extract $(10 \mu \mathrm{g} / \mathrm{ml})$ or $L$. casei extract $(10 \mu \mathrm{g} / \mathrm{ml})$ plus anti-cancer drugs (doxorubicin $10 \mathrm{nM}, 5$-FU $10 \mathrm{nM}$, paclitaxel $10 \mathrm{nM}$, cisplatin $10 \mathrm{nM}$ ) for 72 hours. Annexin $V$ staining was performed in accordance with the manufacturer's protocol (BD Pharmingen, NJ, USA). Trypsin-EDTA was used to obtain single-cell suspensions. After centrifugation, the cells were washed twice with cold PBS and re-suspended in a binding buffer (10 mM HEPES, pH 7.4, $150 \mathrm{mM} \mathrm{NaCl}$, $5 \mathrm{mM} \mathrm{KCl}, 1 \mathrm{mM} \mathrm{MgCl}_{2}$, and $1.8 \mathrm{mM} \mathrm{CaCl}_{2}$ ) at a concentration of $1 \times 10^{6}$ cells $/ \mathrm{ml}$. An aliquot $(100 \mu \mathrm{l})$ containing $1 \times$ $10^{5}$ cells was transferred to a $5 \mathrm{ml}$ culture tube, and $5 \mu \mathrm{l}$ each of Annexin V-FITC and PI were added. After vortexing the tubes, the cells were incubated for 15 minutes at room temperature $\left(25^{\circ} \mathrm{C}\right)$ in the dark and $400 \mu$ of binding buffer was added to each tube. Flow cytometry was performed with the FACS Calibur system within 1 hour.

\section{Statistical analysis}

All data were compiled from a minimum of three replicate experiments and expressed as means \pm standard errors. Student's t-test was used to compare treated cells with control cells. A $p$-value less than 0.05 was considered statistically significant.

\section{Results}

Effect of Lactobacillus casei extract on the growth rate of cervical cancer cells

To observe the effects of $L$. casei extract on cancer cell growth, two cell lines (CaSki, HeLa) were treated with the extract at several concentrations (Fig. 1). There was evidence of growth inhibition at $10 \mu \mathrm{g}$, but the effect was not statistically significant.

Analysis of the cell cycle in Lactobacillus caseitreated cells

The results of cell cycle analysis showed a tendency towards cell cycle changes, but they were again not statistically significant (Fig. 2). In cell cycle analysis by PI staining, there was a $4 \%$ increase in the DNA content of Caski cells in the G0/G1 phase (Fig. 2A), whereas the HeLa cells showed a $2 \%$ increase in DNA content in the $S$ phase (Fig. 2B).

Effect of Lactobacillus casei extract and anticancer drugs on growth of CaSki and HeLa cells

To measure any enhanced effect of $L$. casei extract plus anti-cancer drugs, CaSki and HeLa cells were treated with L. casei extract alone, anti-cancer drugs alone (doxorubicin 
A
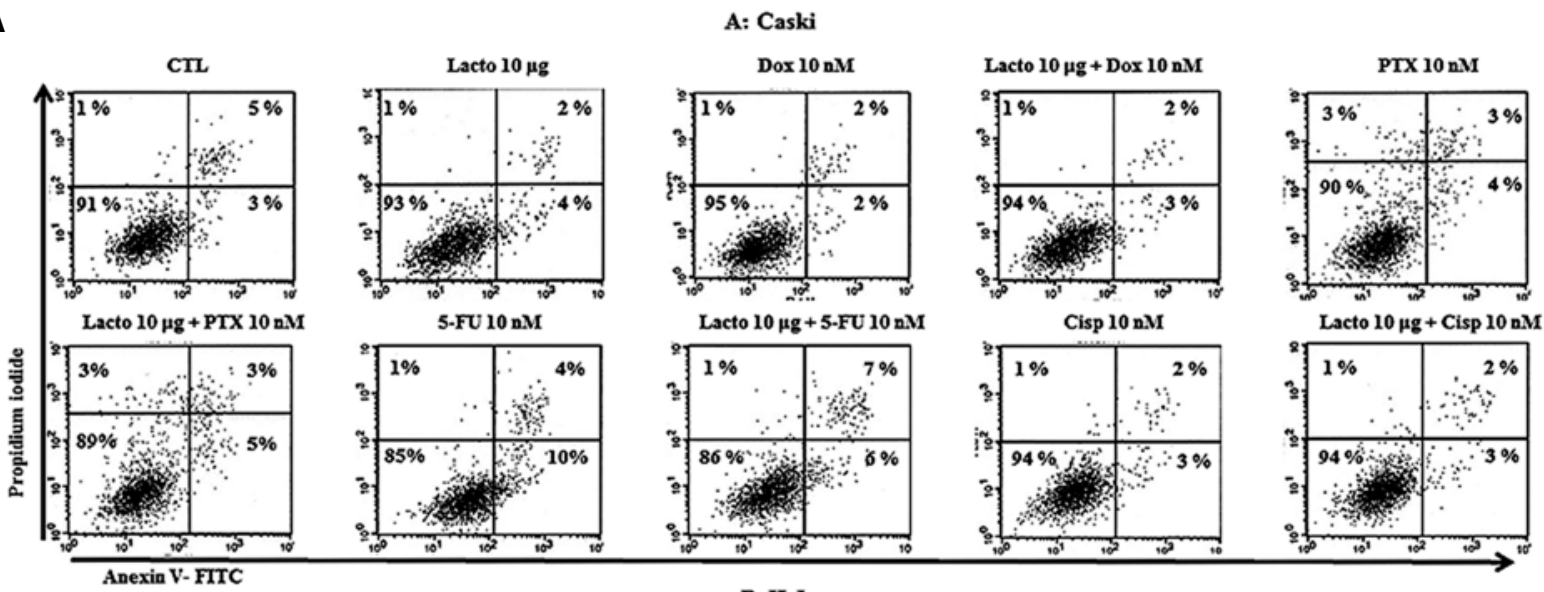

B
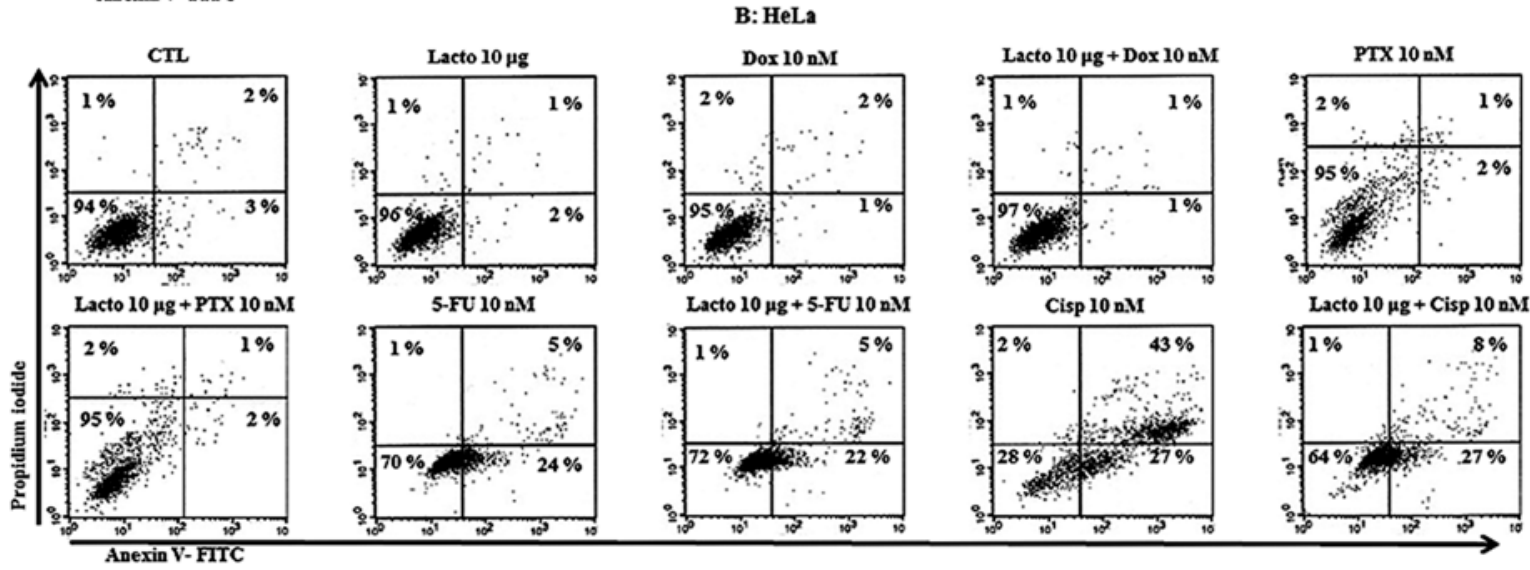

Lacto $10 \mu \mathrm{g}+$ Cisp $10 \mathrm{nM}$

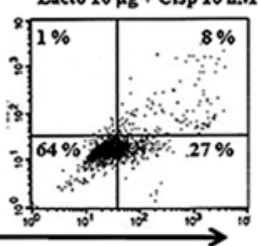

Fig. 5. Cell death analysis after treatment of CaSki and HeLa cells with L. casei extract and anti-cancer drugs. A) CaSki cells. B) HeLa cells. Aliquots of $5 \times 10^{5}$ cells were seeded in Dulbecco's modified Eagle's medium (DMEM) containing 10\% foetal bovine serum (FBS). Cells were treated with distilled water, followed by L. casei extract $(10 \mathrm{\mu g} / \mathrm{ml}$ ), anti-cancer drugs (doxorubicin $10 \mathrm{nM}$, 5-fluoruracil (5-FU) $10 \mathrm{nM}$, paclitaxel $10 \mathrm{nM}$, cisplatin $10 \mathrm{nM}$ ), or L. casei extract $(10 \mathrm{\mu g} / \mathrm{ml}$ ) plus anti-cancer drugs (doxorubicin $10 \mathrm{nM}, 5$-FU $10 \mathrm{nM}$, paclitaxel $10 \mathrm{nM}$, cisplatin $10 \mathrm{nM}$ ) for 72 hours. Cell death was analysed by annexin V staining using flow cytometry. For each treatment, the percentage of viable cells is shown in the lower left quadrant

$10 \mathrm{nM}$, 5-FU $10 \mathrm{nM}$, paclitaxel $10 \mathrm{nM}$, cisplatin $10 \mathrm{nM}$ ), or L. casei extract plus anti-cancer drugs (doxorubicin $10 \mathrm{nM}$, 5-FU $10 \mathrm{nM}$, paclitaxel $10 \mathrm{nM}$, cisplatin $10 \mathrm{nM}$ ). All of the anti-cancer drugs inhibited the growth of these cells, but L. casei extract had no additional effect (Fig. 3A, B).

Effect of Lactobacillus casei extract and anti-cancer drugs on the cell cycle in CaSki and HeLa cells

The cell cycle is associated with growth rate in cancers. The effect of $L$. casei extract plus anti-cancer drugs on the cell cycle was studied by growing the cells as above. The cell cycles of both CaSki and HeLa cells were affected in response to $L$. casei extract. There was a $7 \%$ increase in $\mathrm{S}$ phase cells when CaSki cells were exposed to doxorubicin and a 10\% increase when the cells were exposed to 5-FU plus L. casei extract (Fig. 4A). Similarly there was a 5\% increase in $\mathrm{S}$ phase cells when HeLa cells were incubated with paclitaxel, a 20\% increase with 5-FU, and a 31\% increase when treated with cisplatin plus $L$. casei extract (Fig. 4B). Thus, L. casei extract is potently associated with cell cycle arrest, but has no synergistic effect on growth inhibition in cervical cancer cells.
Effects of Lactobacillus casei extract and anticancer drugs on cell death in CaSki and HeLa cells

The effects of chemotherapeutic drugs on CaSki and HeLa cells were investigated by measuring apoptosis using annexin $\vee$ staining. There was no synergistic effect on cell death when CaSki cells were treated with $L$. casei extract and anti-cancer drugs (doxorubicin 10 nM, 5-FU 10 nM, paclitaxel $10 \mathrm{nM}$, cisplatin $10 \mathrm{nM}$ ) (Fig. 5A). There was also no enhanced effect on cell death in HeLa cells when exposed to $L$. casei extract and the following anti-cancer drugs: doxorubicin $10 \mathrm{nM}, 5-\mathrm{FU} 10 \mathrm{nM}$, and paclitaxel $10 \mathrm{nM}$. However, when HeLa cells were treated with $L$. casei extract and cisplatin, there was a $36 \%$ increase in survival compared with other anti-cancer drugs (Fig. 5B).

\section{Discussion}

Several strains of Lactobacillus have potent anti-tumour effects in rodents [14]. Lactobacillus casei potentiates systemic immune responses in mouse models of colon cancer [15] and reduces tumour induction when given orally [16]. Lactobacillus casei potentiates systemic immune responses that modify T-cell functions in mice and induces 
a cellular immune response that inhibits tumour growth after peritoneal inoculation [17]. Orally administered L. casei has an inhibitory effect on the recurrence of superficial bladder cancer [18]. These results indicate that L. casei may have anti-cancer effects in humans. However, the anti-tumour activity of $L$. casei on cervical cancer has not been reported previously.

This study examined the effect of $L$. casei extract on the following cervical cancer cell lines (CaSki, HeLa). The mechanism of anti-cancer activity of L. casei is not known. Soluble polysaccharide components from Lactobacilli strains exhibit inhibitory activity in cancer cell lines [19] and a cell-wall-derived peptidoglycan has anti-cancer activity [20]. We therefore used whole extract of L. casei. In this study, the extract did not affect the growth of women's cancer cell lines, and there was no synergistic effect after concomitant administration of one or more chemotherapeutic drugs. Instead, we found that $L$. casei extract mainly induced enhanced S-phase cell cycle arrest in cervical cancer cells when administered together with anti-cancer drugs other than 5-FU. In contrast to the effect on the cell cycle, one chemotherapeutic drug (cisplatin) had an inhibitory effect on apoptosis when administered together with L. casei extract. Thus, L. casei extract may have an anti-cancer effect in cervical cancer through an effect on cell cycle arrest, although it has no effect on growth inhibition or any synergistic effect on women's cancer cell growth when administered together with a chemotherapeutic drug.

The cell cycle is the most important factor involved in cancer progression and growth [21]. Molecules involved in the cell cycle have therefore been targeted to inhibit the growth rate of several types of cancer. With respect to cell cycle arrest in cancer growth, we reported previously that L. casei extract arrested the cell cycle and induced growth inhibition in liver cancer [8]. Matsuki et al. reported a direct effect of $L$. casei on growth inhibition [22]. In a co-culture system of $L$. casei with intestinal epithelial cells, they showed that $L$. casei down-regulated cell cycle expression of cyclin E1 and D1, and caused growth inhibition [22]. These results indicate that $L$. casei has an effect on growth inhibition through cell cycle arrest.

In contrast to its effect on the cell cycle, cisplatin inhibited cell death when administered together with L. casei extract. This may result from a high-dose effect on cell growth. In our study, cisplatin induced more than $90 \%$ inhibition of growth in HeLa cells. However, although this result is significant, it may result from experimental error; it is possible that the effect of $L$. casei extract on cell death may be the result of using an inappropriate dose of cisplatin. Therefore, the effect of $L$. casei extract on inhibition of cell death requires further examination by several different methods.

A limitation of this study was that we applied L. casei extract directly to the cancer cells in vitro, since there is no objective in vivo means of measuring L. casei absorption into the human body. Further studies of immunologic responses, other pathways of growth inhibition, in vivo effects, and physical changes due to long-term intake of L. casei extract are required in in vivo cancer models.
In conclusion, direct treatment with $L$. casei extract has no effect on the growth of cervical cancer cell lines CaSki and HeLa, and it has no synergistic effect with the chemotherapeutic agents tested in this study.

The authors declare no conflict of interest.

This study was supported by Konkuk University in 2011.

\section{References}

1. Dogi CA, Galdeano CM, Perdigón G. Gut immune stimulation by non-pathogenic Gram(+) and Gram(-) bacteria. Comparison with a probiotic strain. Cytokine 2008; 41: 223-31.

2. Taranto MP, Vera JL, Hugenholtz J, De Valdez GF, Sesma F. Lactobacillus reuteri CRL1098 produces cobalamin. J Bacteriol 2003; 185: 5643-7.

3. Kimoto-Nira H, Aoki R, Mizumachi K, Sasaki K, Naito H, Sawada T, Suzuki C. Interaction between Lactococcus lactis and Lactococcus raffinolactis during growth in milk: development of a new starter culture. J Dairy Sci 2012; 95: 2176-85.

4. Sharma M, Devi M. Probiotics: a comprehensive approach toward health foods. Crit Rev Food Sci Nutr 2014; 54: 537-52.

5. So JS, Lee CG, Kwon HK, Yi HJ, Chae CS, Park JA, Hwang KC, Im $\mathrm{SH}$. Lactobacillus casei potentiates induction of oral tolerance in experimental arthritis. Mol Immunol 2008; 46: 172-80.

6. Teanpaisan R, Hintao J, Dahlén G. Oral Lactobacillus species in type 2 diabetic patients living in southern Thailand. Anaerobe 2009; 15: 160-3.

7. Katayama Y. The antitumor activity of Lactobacillus casei - the direct effects of $L$. casei to human tumor cell lines. Kansenshogaku zasshi 1990; 64: 781-6.

8. Han DJ, Kim JB, Park SY, Yang MG, Kim H. Growth inhibition of hepatocellular carcinoma Huh7 cells by Lactobacillus casei extract. Yonsei Med J 2013; 54: 1186-93.

9. Lim MC, Moon EK, Shin A, et al. Incidence of cervical, endometrial, and ovarian cancer in Korea, 1999-2010. J Gynecol Oncol 2013; 24: 298-302.

10. Jess PR, Smith DD, Mazilu M, Dholakia K, Riches AC, Herrington CS. Early detection of cervical neoplasia by Raman spectroscopy. Int J Cancer 2007; 121: 2723-8.

11. Phongsavan K, Gustavsson I, Marions L, Phengsavanh A, Wahlström R, Gyllensten U. Detection of human papillomavirus among women in Laos: feasibility of using filter paper card and prevalence of high-risk types. Int J Gynecol Cancer 2012; 22: 1398-406.

12. Gillet E, Meys JF, Verstraelen H, Bosire C, De Sutter P, Temmerman $M$, Broeck DV. Bacterial vaginosis is associated with uterine cervical human papillomavirus infection: a meta-analysis. BMC Infect Dis 2011; 11: 10.

13. Krishnan AV, Swami S, Feldman D. Equivalent anticancer activities of dietary vitamin $D$ and calcitriol in an animal model of breast cancer: importance of mammary CYP27B1 for treatment and prevention. J Steroid Biochem Mol Biol 2013; 136: 289-95.

14. Kato I, Kobayashi S, Yokokura T, Mutai M. Antitumor activity of Lactobacillus casei in mice. Gann 1981; 72: 517-23.

15. Kato I, Endo-Tanaka K, Yokokura T. Suppressive effects of the oral administration of Lactobacillus casei on type II collagen-induced arthritis in DBA/1 mice. Life Sci 1998; 63: 635-44.

16. Takagi A, Matsuzaki T, Sato M, Nomoto K, Morotomi M, Yokokura T. Inhibitory effect of oral administration of Lactobacillus casei on 3-methylcholanthrene-induced carcinogenesis in mice. Med Microbiol Immunol 1999; 188: 111-6.

17. Kato I, Yokokura T, Mutai M. Induction of tumoricidal peritoneal exudate cells by administration of Lactobacillus casei. Int I Immunopharmacol 1985; 7: 103-9.

18. Nanno M, Kato I, Kobayashi T, Shida K. Biological effects of probiotics: what impact does Lactobacillus casei shirota have on us? Int J Immunopathol Pharmacol 2011; 24: 45S-50S. 
19. Choi SS, Kim Y, Han KS, You S, Oh S, Kim SH. Effects of Lactobacillus strains on cancer cell proliferation and oxidative stress in vitro. Lett Appl Microbiol 2006; 42: 452-8.

20. Fichera GA, Giese G. Non-immunologically-mediated cytotoxicity of Lactobacillus casei and its derivative peptidoglycan against tumor cell lines. Cancer Lett 1994; 85: 93-103.

21. Gunde T, Barberis A. Yeast growth selection system for detecting activity and inhibition of dimerization-dependent receptor tyrosine kinase. BioTechniques 2005; 39: 541-9.

22. Matsuki T, Pédron T, Regnault B, Mulet C, Hara T, Sansonetti PJ. Epithelial cell proliferation arrest induced by lactate and acetate from Lactobacillus casei and Bifidobacterium breve. PLoS One 2013; 8: e63053.

\section{Address for correspondence}

\section{Jaeman Bae}

Konkuk University Medical Center

Seoul, South Korea

e-mail:snkim@chol.com

Submitted: 16.05 .2014

Accepted: $\quad 7.08 .2014$ 